\title{
Men assigned to ethylene oxide production or other ethylene oxide related chemical manufacturing: a mortality study
}

\author{
H L Greenberg, M G Ott, R E Shore
}

\begin{abstract}
A retrospective cohort study was conducted to examine the mortality experience of 2174 men employed between 1940 and 1978 by a large chemical company and who had been assigned to a chemical production department that used or produced ethylene oxide (EO). Comparisons were made with the general United States population, the regional population, and with a group of 26965 unexposed men from the same plants. Comparisons with general United States death rates showed fewer deaths than expected in the EO group due to all causes and for total cancers. There was no statistically significant excess of deaths due to any cause. Seven deaths each due to leukaemia and pancreatic cancer were observed with 3.0 and 4.1 deaths expected. Among the subcohort of men who worked where both average and peak exposure levels were probably highest, however, one death due to pancreatic cancer $(0.9$ expected) and no deaths due to leukaemia were observed. Four of the seven who died from leukaemia and six of the seven who died from pancreatic cancer had been assigned to the chlorohydrin department where the potential for exposure to EO is judged to have been low. The relative risk of death due to each disease was strongly related to duration of assignments to that department. When men who worked in the chlorohydrin department were excluded, there was no evidence for an association of exposure to EO with pancreatic cancer or leukaemia. Together with the failure to show independent EO associations, the chlorohydrin department results suggest that leukaemia and pancreatic cancer may have
\end{abstract}

Union Carbide Corporation, Danbury, CT 06817001, USA

H L Greenberg, M G Ott

Department of Environmental Medicine, New York University, New York, New York 10010

R E Shore been associated primarily with production of ethylene chlorohydrin or propylene chlorohydrin, or both. These results emphasise the importance of examining additional concurrent/asynchronous exposures among human populations exposed to EO.

Ethylene oxide (EO) is a major industrial chemical with an annual production capacity in the United States in the range of six billion pounds. ${ }^{1}$ Most EO produced is used to manufacture chemical derivatives, less than $0.5 \%$ is consumed by sterilant or fumigant users.

Because EO is flammable and highly reactive, process equipment in the manufacturing setting generally consists of tightly closed and highly automated systems. Currently, during routine operation, workers have minimal opportunity for exposure and levels in chemical manufacturing plants are typically low, usually less than $1 \mathrm{ppm}$, the current eight hour time weighted average (TWA8) standard. ${ }^{2}$ Historical exposure levels are known to have been higher, however. In industries that use EO for sterilisation, the control of employee exposures may be more difficult due to the greater potential for workers to have physical contact with $\mathrm{EO}$ gas.

EO has been shown to be an alkylating agent, which may react directly (and irreversibly) with nucleophilic macromolecules (such as DNA, RNA, and proteins) without requiring metabolic activation..$^{3-5}$ It is genotoxic in a wide variety of biological systems and carcinogenic in rats and mice. $^{6-9}$

Hogstedt et al have reported excesses of leukaemia among sterilant workers and leukaemia and stomach cancer among employees of a chemical production plant. $^{10-12}$ Mortality studies of several other occupational cohorts have been reported that do not support these findings. ${ }^{13-15}$ Bisanti et al also did not observe an excess of leukaemia in Italian chemical workers but reported excesses of lymphosarcoma and cancers of the digestive system (L Bisanti et al, sixth international symposium of epidemiology in occupational health, Stockholm, 1988).

The present research is based on the follow up of 
2174 men who were employed between 1940 and 1978 at either of two Union Carbide Corporation (UCC) chemical production plants and who were assigned to chemical manufacturing operations that produced EO or used it in the production of derivatives.

\section{Materials and methods}

ETHYLENE OXIDE PRODUCTION AND USE

EO production at the South Charleston, West Virginia, plant began when the plant opened in 1925, using the chlorohydrin process exclusively. Chlorohydrin based EO production used crude ethylene chlorohydrin pumped in from the chlorohydrin department. In 1937 production of EO by the direct oxidation of ethylene gas went on line. By 1941, EO was being manufactured at South Charleston by three converters using the chlorohydrin method and by three more using direct oxidation. Chlorohydrin based EO production was shut down in 1957. Between 1948 and 1950, five direct oxidation EO converters were constructed and began production at UCC's Institute, West Virginia, plant.

In 1970 and 1971 EO manufacturing at the Institute and South Charleston facilities was phased out. EO for remaining production was shipped to Institute by rail and supplied to South Charleston from Institute by pipeline. The use of EO in Kanawha Valley derivatives operations remained substantial, however.

\section{COHORT DESCRIPTION}

The study cohort was drawn from a base file of 29139 male employees of UCC who had ever been employed at any of the three UCC facilities in the Kanawha Valley (KV) of West Virginia (the two production plants and a technical centre) between 1940 and 1978. The mortality experience of this group has been previously reported. ${ }^{16}$

A detailed historical reconstruction of chemical processing at the two production facilities had been produced by veteran manufacturing personnel who reviewed available records and prepared chronological listings of substances present in each chemical processing department as far back as $1925 .{ }^{17}$ Each production department was described in terms of start up and shut down dates and included an inventory of chemicals used and produced.

Work history records of all employees in the base file were searched and individuals were identified who had ever been assigned by 1979 to a chemical production department that was judged to have used or produced EO (study departments). Records of identified employees were further examined to ensure that their inclusion in the cohort was based on assignment during a period when EO was handled.

Study members were not included based on main- tenance assignments to EO departments, since their
work history records did not typically provide department specific information. Eligible study subjects, however, may have also been assigned to등 maintenance jobs at some point in their employment.

ENVIRONMENTAL ASSESSMENT

Taken together, the study departments represented a $\vec{O}$ diverse group of chemical manufacturing activities, $\vec{\overrightarrow{ }}$ ranging from the production of EO by two different ${ }_{\sigma}^{\omega}$ methods (chlorohydrin process and direct oxidation) $\bar{O}$ to its use in the production of numerous other $\stackrel{\Phi}{3}$ chemicals. In some departments EO was used in the manufacture of virtually every product; in others it ${ }_{A}$ was used in small quantities, in a small minority of operations, or both. Study departments thus differed ${ }_{-}$ from one another not only on the basis of potential $\mathrm{O}$ exposure to EO but also on the basis of exposures toother substances.

The first large scale environmental monitoring programme for EO began in 1976. Results indicated $\overrightarrow{0}$ that TWA8 EO exposure levels in EO based chemical 8 production departments averaged less than $1 \mathrm{ppm}$, although exposure levels as high as $66 \mathrm{ppm}$ TWA8 had been observed. Exposure levels among maintenance employees were generally between 1 and $5 \mathrm{ppm}$ TWA8. Although these data were useful in charac- $\frac{\circ}{\square}$ terising ambient EO levels in departments operating $\cong$ at that time, they were of limited use for assessment $\overrightarrow{\bar{O}}$ of pre-1976 concentrations. An exposure categorisa- 3 tion scheme was therefore developed that did not rely on monitoring data, recognised the multiple agents in the environment as well as relative EO exposure levels, and reflected any changes that occurred over $\stackrel{\Phi}{\exists}$ time (table 1). Department specific data on the factors affecting potential for exposures to EO and exposures to other substances were obtained by interviews and by reference to available records.

Three EO exposure levels were defined. EO 0 production departments with one or more con- $D$ tinuously operating EO converters and recovery systems were considered to have the highest potential $\hat{\sim}$ for EO exposure, as a result of routine activities ? such as frequent sampling, maintenance of cycle $N$ machines, and EO compressors. Departments using $N$ EO were considered to be in the intermediate level if: $\bar{O}$ (1) EO was routinely in use in systems that were indoors in the same building as the operators and there was no pressurised control room, (2) the $\stackrel{\infty}{+}$ department was developmental or the process tended 7 to lose EO during routine operations, or (3) the $\overline{0}$ department also produced EO but did not have its $\stackrel{\mathbb{Q}}{\mathbb{Q}}$ own recovery system and therefore was not con- $\mathbb{\mathbb { Q }}$ sidered to be a high exposure department. Remaining departments using EO were considered to have the lowest potential for exposure and were assigned to the low exposure category. 
Table 1 Categorisation of study departments by work area and ethylene oxide exposure level

\begin{tabular}{|c|c|c|c|c|c|}
\hline & \multirow[b]{2}{*}{ Work area } & \multicolumn{3}{|c|}{$\begin{array}{l}\text { No of study departments at } \\
\text { stated EO exposure level }\end{array}$} & \multirow[b]{2}{*}{ Other substances commonly present in work area } \\
\hline & & Low & Int & High & \\
\hline I & $\begin{array}{l}\text { Oxide distribution, } \\
\text { polymerisation, and } \\
\text { aducts; glycol ethers and } \\
\text { amines }\end{array}$ & 10 & 10 & 2 & $\begin{array}{l}\text { Aliphatic and alkanolamines, aliphatic and aromatic alcohols, } \\
\text { ammonia, caustic, glycol ethers, and inorganic acids }\end{array}$ \\
\hline II & $\begin{array}{l}\text { Chlorohydrin users and } \\
\text { producers }\end{array}$ & 5 & 1 & 2 & $\begin{array}{l}\text { Acetaldehyde, aliphatic alcohols and amines, allyl chloride, } \\
\text { ammonia, bis-chloroethyl ether, caustic, chlorine, dichloroethane, } \\
\text { dioxane, ethylene and propylene chlorohydrin, epichlorohydrin, } \\
\text { glycol ethers, and inorganic acids }\end{array}$ \\
\hline III & $\begin{array}{l}\text { Specialty chemicals; } \\
\text { oxide production; } \\
\text { polyalkylene glycol } \\
\text { ethers, diols, and triols }\end{array}$ & 6 & 2 & 2 & $\begin{array}{l}\text { Acetonitrile, acrolein, acrylonitrile, aldehydes, aliphatic alcohols, } \\
\text { aniline, benzene, butadiene, caustic, diethyl sulphate, } \\
\text { epichlorohydrin, ethylene dichloride, formaldehyde, glycol ethers, } \\
\text { methylene chloride, styrene, and toluidine }\end{array}$ \\
\hline
\end{tabular}

\section{MEDICAL RECORD REVIEW}

Because EO is acutely toxic, exposed employees often reported to the dispensary for examination or treatment. Beginning in 1950, an acute exposure log was maintained at the Institute plant dispensary. To test the consistency of the environmental characterisation, the frequencies of reported exposures were calculated by the EO exposure level (low, intermediate, high) of the departmental assignment at the time and by maintenance or distribution assignment.

Skin and eye contact were the most frequently reported exposures to EO. Most were reported by men assigned to producing $\mathrm{EO}$ where the calculated frequency of such exposures was 31.5/1000 personyears (PY) of assignment. The frequency of these exposures among men assigned to intermediate and low EO levels were 6.0 and $6.4 / 1000 \mathrm{PY}$, respectively, and they were least frequent for men assigned to maintenance or distribution departments (2.3/ $1000 \mathrm{PY}$ ). Inhalation exposures resulting in nausea and vomiting were also most frequently reported among men assigned to EO production (6.9/1000 PY). Exposure frequencies decreased with decreasing EO level (intermediate 2.0/1000 PY; low 1.2/1000 PY) and were lowest for the maintenance/distribution subgroup $(0 \cdot 2 / 1000 \mathrm{PY})$.

\section{ANALYSIS}

Traditional standardised mortality ratio (SMR) analyses were used to examine the mortality experience of the total study cohort and subgroups of interest compared with that of the general United States population or the regional population of Kanawha and Putnam counties. Comparisons were performed using a modified life table approach and white male death rates for the general United States population. ${ }^{18}$ Regional comparisons used rates developed by the University of Pittsburgh.

Person-years were accumulated into five year age and calendar year specific intervals beginning with the date of hire or 1 January 1940 , whichever was later. Cohort members continued to contribute PY until lost to follow up (in which case they were withdrawn alive on the date last observed), death, or 31 December 1978, whichever occurred first. Ninety five per cent confidence limits were computed using the programs of Rothman and Boice. ${ }^{19}$

Mantel-Haenszel extension analyses for a cohort study were used to evaluate trends in the relative risk for hypothesised cause specific mortality over levels of duration of EO assignments. ${ }^{2021}$ The non-EO exposed $\mathrm{KV}$ population was used as an internal comparison group. Analyses were stratified by age, calendar year, and interval since hire. Level specific relative risk estimates were standardised to the referent level and $95 \%$ confidence intervals were calculated using the variance estimator described by Robins et al. $^{22}$ Trend analyses were also performed after incorporating a series of lags $(5,10$, or 20 years) into the calculation of the exposure variable. In these analyses the dose-response relation (where duration of assignment was used as a surrogate for dose) was tested using the methodology developed by Pasternack and Shore. ${ }^{23}$

\section{Results}

The vital and employment status of the 2174 men in the study cohort is summarised in table 2 . At the end of $1978,37 \%$ were employed; $48 \%$ had left employment with UCC in the KV and were known to be alive; $14 \%$ had died and the vital status of less than $2 \%$ was unknown. Death certificates were collected for all but five of the 297 known decedents.

Slightly over $10 \%$ of the cohort had been first assigned to a study department before 1940. Their inclusion in the study occurred because they remained on the payroll as of 1 January 1940. Almost two thirds of the deaths occurred among men hired before or during the 1940s. Thus the overall study results largely reflect the mortality patterns of men 
Table 2 Vital and employment status of the ethylene oxide (EO) cohort by decade of first EO assignment and total duration of assignments to EO using/producing departments as of 31 December 1978

\begin{tabular}{|c|c|c|c|c|c|}
\hline \multirow[b]{2}{*}{$\begin{array}{l}\text { Decade of first EO } \\
\text { assignment and duration } \\
\text { of EO employment }\end{array}$} & \multicolumn{3}{|l|}{ Known alive } & \multirow[b]{2}{*}{$\begin{array}{l}\text { Dead } \\
(n=297)\end{array}$} & \multirow{2}{*}{$\begin{array}{l}\text { Vital } \\
\text { status } \\
\text { unknown } \\
(n=39)\end{array}$} \\
\hline & $\begin{array}{l}\text { Total } \\
(n=2174)\end{array}$ & $\begin{array}{l}\text { Actively } \\
\text { employed } \\
(n=804)\end{array}$ & $\begin{array}{l}\text { Left } \\
(n=1034)\end{array}$ & & \\
\hline $\begin{array}{l}\text { First assignment before } \\
\text { Total } \\
<1 \text { year } \\
1-4 \text { years } \\
5-9 \text { years } \\
10-19 \text { years } \\
20-29 \text { years } \\
\geqslant 30 \text { years }\end{array}$ & $\begin{array}{r}223 \\
28 \\
54 \\
42 \\
40 \\
40 \\
19\end{array}$ & $\begin{array}{l}0 \\
0 \\
0 \\
0 \\
0 \\
0 \\
0\end{array}$ & $\begin{array}{r}108 \\
14 \\
0 \\
23 \\
16 \\
21 \\
12\end{array}$ & $\begin{array}{r}111 \\
14 \\
31 \\
18 \\
22 \\
19 \\
7\end{array}$ & $\begin{array}{l}4 \\
0 \\
1 \\
1 \\
2 \\
0 \\
0\end{array}$ \\
\hline $\begin{array}{l}\text { First assignment } 1940- \\
\text { Total } \\
<1 \text { year } \\
1-4 \text { years } \\
5-9 \text { years } \\
10-19 \text { years } \\
20-29 \text { years } \\
\geqslant 30 \text { years }\end{array}$ & $\begin{array}{r}400 \\
78 \\
83 \\
69 \\
89 \\
66 \\
15\end{array}$ & $\begin{array}{r}61 \\
6 \\
10 \\
13 \\
12 \\
17 \\
3\end{array}$ & $\begin{array}{r}249 \\
52 \\
49 \\
45 \\
54 \\
37 \\
12\end{array}$ & $\begin{array}{r}84 \\
18 \\
23 \\
10 \\
22 \\
11 \\
0\end{array}$ & $\begin{array}{l}6 \\
2 \\
1 \\
1 \\
1 \\
1 \\
0\end{array}$ \\
\hline $\begin{array}{l}\text { First assignment } 1950- \\
\text { Total } \\
<1 \text { year } \\
1-4 \text { years } \\
5-9 \text { years } \\
10-19 \text { years } \\
20-29 \text { years }\end{array}$ & $\begin{array}{r}481 \\
108 \\
148 \\
88 \\
115 \\
22\end{array}$ & $\begin{array}{r}192 \\
23 \\
39 \\
40 \\
72 \\
18\end{array}$ & $\begin{array}{r}235 \\
67 \\
92 \\
42 \\
32 \\
2\end{array}$ & $\begin{array}{r}39 \\
10 \\
15 \\
3 \\
9 \\
2\end{array}$ & $\begin{array}{r}15 \\
8 \\
2 \\
3 \\
2 \\
0\end{array}$ \\
\hline $\begin{array}{l}\text { First assignment } 1960- \\
\text { Total } \\
<1 \text { year } \\
1-4 \text { years } \\
5-9 \text { years } \\
10-19 \text { years }\end{array}$ & $\begin{array}{r}760 \\
253 \\
315 \\
122 \\
70\end{array}$ & $\begin{array}{r}332 \\
59 \\
135 \\
80 \\
58\end{array}$ & $\begin{array}{r}357 \\
176 \\
139 \\
31 \\
11\end{array}$ & $\begin{array}{r}57 \\
13 \\
33 \\
10 \\
1\end{array}$ & $\begin{array}{r}14 \\
5 \\
8 \\
1 \\
0\end{array}$ \\
\hline $\begin{array}{l}\text { First assignment } \geqslant 197 \\
\text { Total } \\
<1 \text { year } \\
1-4 \text { years } \\
5-9 \text { years }\end{array}$ & $\begin{array}{r}310 \\
157 \\
135 \\
18\end{array}$ & $\begin{array}{r}219 \\
87 \\
116 \\
16\end{array}$ & $\begin{array}{r}85 \\
66 \\
17 \\
2\end{array}$ & $\begin{array}{l}6 \\
4 \\
2 \\
0\end{array}$ & $\begin{array}{l}0 \\
0 \\
0 \\
0\end{array}$ \\
\hline
\end{tabular}

who were first assigned to study departments before 1950. The cohort was followed up for an average of 20 years per man.

For the full cohort the SMR for all causes was 79 (p $<0.05$ ) and for total cancers the SMR was 81 (not significant (NS)) (table 3). No statistically significant rises were observed for any cause of death category. Significant deficits were seen for deaths due to diseases of the respiratory system and suicide. Nonsignificantly raised SMRs were observed for deaths due to brain cancer, leukaemia, liver cancer, and cancer of the pancreas. Using regional rates, the mortality patterns of the study group were essentially unchanged, suggesting that regional factors were relatively unimportant.

Mortality patterns for the subcohort assigned to study departments for at least two years were similar to those of the full cohort. To focus on those men with the greatest potential for exposure, the remaining SMR tables are restricted to this subcohort. Only six of the 211 observed deaths in the subcohort were observed among men who were hired into salaried jobs. Consequently, the mortality patterns of the total subcohort primarily reflect the experience of the hourly subset.

Table 4 shows the cause specific mortality for the 8 $\geqslant 2$ years group by EO exposure level. For each level, follow up started on the day two years of $\frac{}{3}$ assignments to departments at that level had $>$ occurred, or 1 January 1940 , whichever was later. The three subcohorts were not mutually exclusive as $N$ cohort members may have been assigned for two years to departments at more than one level. There $\mathcal{O}$ were no statistically raised SMRs for any cause of $N_{\omega}$ death for the subcohort assigned to departments with $\sigma_{0}$ the highest exposure to EO. The SMR for all cancers 0 was 78 (NS) and there were no deaths due to stomach $\frac{\sim}{\Phi}$ cancer, brain cancer, or leukaemia. For the subcohort $\stackrel{+}{+}$ at the intermediate exposure level, there were no 0 statistically significant excesses in any cause of death category and there were no observed deaths due to brain cancer or leukaemia. There were raised SMRs observed for stomach and pancreatic cancers. Among men in the lowest exposure subcohort, there were significantly more deaths than expected for cancer of 8 the pancreas and for lymphatic and haematopoietic 
Table 3 Observed and expected deaths (1940-78) by selected causes for men ever assigned to EO using/producing departments

\begin{tabular}{|c|c|c|c|}
\hline Cause of death category & $O b s / E x p$ & $S M R^{\dagger}$ & $\left(95^{\circ}{ }_{0} C L\right)$ \\
\hline All causes: & $297 / 375 \cdot 9$ & $79^{\star}$ & $(70,89)$ \\
\hline $\begin{array}{l}\text { Malignant neoplasms, total: } \\
\text { Digestive organs \& peritoneum: } \\
\text { Oesophagus } \\
\text { Stomach } \\
\text { Intestine except rectum } \\
\text { Rectum } \\
\text { Liver unspecified and primary } \\
\text { Pancreas } \\
\text { Respiratory system } \\
\text { Male genital organs } \\
\text { Kidney } \\
\text { Bladder and other urinary organs } \\
\text { Skin } \\
\text { Brain and other parts of nervous system } \\
\text { Lymphatic and haematopoietic tissue: } \\
\text { Leukaemia and aleukaemia } \\
\text { Non-Hodgkin's lymphoma } \\
\text { Multiple myeloma } \\
\text { Diabetes mellitus } \\
\text { Vascular lesions affecting CNS } \\
\text { Unable to locate death certificate }\end{array}$ & $\begin{array}{l}60 / 74 \cdot 6 \\
20 / 20 \cdot 3 \\
1 / 1 \cdot 8 \\
3 / 3 \cdot 7 \\
3 / 6 \cdot 4 \\
0 / 2 \cdot 3 \\
3 / 1 \cdot 8 \\
7 / 4 \cdot 1 \\
19 / 26 \cdot 7 \\
2 / 3 \cdot 8 \\
1 / 2 \cdot 0 \\
0 / 1 \cdot 9 \\
1 / 1 \cdot 5 \\
4 / 2 \cdot 8 \\
9 / 7 \cdot 5 \\
7 / 3 \cdot 0 \\
2 / 2 \cdot 4 \\
0 / 0 \cdot 9 \\
1 / 5 \cdot 2 \\
14 / 19 \cdot 9 \\
5\end{array}$ & $\begin{array}{l}81 \\
98 \\
(56) \\
(81) \\
(93) \\
(170) \\
(171) \\
71 \\
(53) \\
(51) \\
(65) \\
(141) \\
120 \\
232 \\
(82) \\
-(19) \\
70\end{array}$ & $\begin{array}{l}(62,104) \\
(60,152) \\
(3,276) \\
(16,237) \\
(34,203) \\
(0,164) \\
(33,498) \\
(69,353) \\
(43,111) \\
(4,190) \\
(2,255) \\
(0,199) \\
(3,312) \\
(38,362) \\
(55,228) \\
(94,478) \\
(6,293) \\
(0,404) \\
(1,109) \\
(39,118)\end{array}$ \\
\hline
\end{tabular}

ॠSMR is statistically different from 100 ( $p<0.05$, two tailed).

+Parenthetical values in the SMR column indicate observed to expected ratios for which the numerator or denominator or both is less than 5 .

malignancies, which were attributable to an excess of leukaemia. There were non-significantly raised SMRs for cancer of the brain and non-Hodgkin's lymphoma. Additional analyses performed to pinpoint a more specific subcohort from which these excesses arose identified the group of men who had been assigned to the chlorohydrin department.

Table 5 shows the results of the SMR analysis of this group. Statistically significant excess mortality was observed for pancreatic cancer ( $6 \mathrm{obs} / 0 \cdot 7 \mathrm{exp})$ and leukaemia ( 3 obs $/ 0.4 \mathrm{exp}$ ). For the remainder of the cohort never assigned to the chlorohydrin department, there was one death from pancreatic cancer (2.2 exp) and three from leukaemia (1.5 exp). These findings were supported by trends with duration of assignment to the chlorohydrin department (table 6). Compared with the non-EO group, the relative risks for pancreatic cancer and leukaemia were 14 and 8.7fold, respectively, for those with 10 or more years of chlorohydrin department assignments. Lagged analyses by duration of chlorohydrin assignments performed for these diseases showed trends that grew steeper and remained highly significant as the assumed induction period increased from 0 to 20 years. No trends for mortality due to either stomach or brain cancer were observed with duration in all study departments or specifically in the chlorohydrin department.

Table 4 Observed and expected deaths (1940-78) by selected causes for men assigned to EO using/producing departments for two years or more

\begin{tabular}{|c|c|c|c|c|c|c|}
\hline \multirow[b]{2}{*}{ Cause of death category } & \multicolumn{2}{|c|}{$\begin{array}{l}\text { Assigned for } \geqslant 2 \text { years to low } \\
\text { exposure depts }\end{array}$} & \multicolumn{2}{|c|}{$\begin{array}{l}\text { Assigned for } \geqslant 2 \text { years to int } \\
\text { exposure depts }\end{array}$} & \multicolumn{2}{|c|}{$\begin{array}{l}\text { Assigned for } \geqslant 2 \text { years to } \\
\text { high exposure depts }\end{array}$} \\
\hline & $O b s / E x p$ & $S M R^{\star}$ & $O b s / E x p$ & $S M R^{\star}$ & $O b s / E x p$ & $S M R^{\dagger}$ \\
\hline All causes & $118 / 150 \cdot 5$ & $78+$ & $69 / 78 \cdot 2$ & 88 & $58 / 83 \cdot 7$ & 694 \\
\hline $\begin{array}{l}\text { Malignant neoplasms, total: } \\
\text { Digestive organs and peritoneum: } \\
\text { Stomach } \\
\text { Pancreas } \\
\text { Respiratory system } \\
\text { Brain and other parts of NS } \\
\text { Lymphatic and haematopoietic tissue: } \\
\text { Leukaemia and aleukaemia } \\
\text { Non-Hodgkin's lymphoma } \\
\text { Multiple myeloma } \\
\text { Unable to locate death certificate }\end{array}$ & $\begin{array}{l}31 / 31 \cdot 4 \\
12 / 8 \cdot 6 \\
1 / 1 \cdot 5 \\
7 / 1 \cdot 8 \\
8 / 11 \cdot 6 \\
2 / 1 \cdot 1 \\
8 / 2 \cdot 9 \\
6 / 1 \cdot 2 \\
2 / 1 \cdot 0 \\
0 / 0 \cdot 4 \\
1\end{array}$ & $\begin{array}{l}99 \\
140 \\
(66) \\
(400) \ddagger \\
69 \\
(184) \\
(275) \S \\
(517) \\
(204) \\
-\end{array}$ & $\begin{array}{l}10 / 15 \cdot 7 \\
8 / 4 \cdot 4 \\
3 / 0 \cdot 8 \\
2 / 0 \cdot 9 \\
1 / 5 \cdot 6 \\
0 / 0 \cdot 6 \\
1 / 1 \cdot 5 \\
0 / 0 \cdot 6 \\
1 / 0 \cdot 5 \\
0 / 0 \cdot 2 \\
1\end{array}$ & $\begin{array}{l}64 \\
(182) \\
(364) \\
(229) \\
(18) \\
\frac{(67)}{(203)} \\
-\end{array}$ & $\begin{array}{l}13 / 16 \cdot 8 \\
4 / 4 \cdot 6 \\
0 / 0 \cdot 9 \\
1 / 0 \cdot 9 \\
7 / 6 \cdot 0 \\
0 / 0 \cdot 6 \\
0 / 1 \cdot 7 \\
0 / 0 \cdot 7 \\
0 / 0 \cdot 6 \\
0 / 0 \cdot 2 \\
1\end{array}$ & $\begin{array}{l}78 \\
(87) \\
\overline{(109)} \\
116 \\
= \\
= \\
=\end{array}$ \\
\hline
\end{tabular}

* Parenthetical values in the SMR column indicate observed to expected ratios for which the numerator or denominator or both is less than 5 .

$95^{\circ}{ }_{0}$ Confidence limits: $+(65,94), \ddagger(164,817), \S(120,541),:(196,1107), \uparrow(53,89)$. 
Table 5 Observed and expected deaths (1940-78) by selected causes and by assignments to the chlorohydrin department among men assigned for two years or more to EO using/producing departments

\begin{tabular}{|c|c|c|c|c|c|c|}
\hline \multirow[b]{2}{*}{ Cause of death category } & \multicolumn{3}{|c|}{ Assigned for $\geqslant 2$ years to chlorohydrin dept } & \multicolumn{3}{|c|}{$\begin{array}{l}\text { Assigned for } \geqslant 2 \text { years to } E O \text {, never to } \\
\text { chlorohydrin dept }\end{array}$} \\
\hline & $O b s / E x p$ & $S M R \dagger$ & $95 \% C L$ & $O b s / E x p$ & $S M R \dagger$ & $95 \% \mathrm{CL}$ \\
\hline All causes & $61 / 59 \cdot 5$ & 103 & $(79,132)$ & $140 / 191 \cdot 8$ & $73^{\star}$ & $(62,86)$ \\
\hline $\begin{array}{l}\text { Malignant neoplasms, total: } \\
\text { Digestive organs and peritoneum: } \\
\text { Stomach } \\
\text { Pancreas } \\
\text { Respiratory system } \\
\text { Brain and other parts of NS } \\
\text { Lymphatic and haematopoietic tissue: } \\
\text { Leukaemia and aleukaemia } \\
\text { Non-Hodgkin's lymphoma } \\
\text { Multiple myeloma } \\
\text { Unable to locate death certificate }\end{array}$ & $\begin{array}{l}18 / 11 \cdot 7 \\
8 / 3 \cdot 4 \\
0 / 0 \cdot 7 \\
6 / 0 \cdot 7 \\
4 / 4 \cdot 1 \\
1 / 0 \cdot 4 \\
4 / 1 \cdot 1 \\
3 / 0 \cdot 4 \\
1 / 0 \cdot 3 \\
0 / 0 \cdot 1 \\
1\end{array}$ & $\begin{array}{l}153 \\
(233)^{\star} \\
(911)^{\star} \\
(99)^{\star} \\
(263) \\
(376)^{\star} \\
(668)^{\star} \\
(291)^{-}\end{array}$ & $\begin{array}{l}(91,242) \\
(102,459) \\
(0,549) \\
(355,1898) \\
(26,253) \\
(13,1394) \\
(103,958) \\
(139,1895) \\
(14,1564) \\
(0,2564)\end{array}$ & $\begin{array}{l}25 / 39 \cdot 1 \\
9 / 10 \cdot 5 \\
3 / 1 \cdot 9 \\
1 / 2 \cdot 2 \\
9 / 14 \cdot 4 \\
1 / 1 \cdot 5 \\
4 / 3 \cdot 9 \\
3 / 1 \cdot 5 \\
1 / 1 \cdot 3 \\
0 / 0 \cdot 5 \\
0\end{array}$ & $\begin{array}{l}64^{\star} \\
85 \\
(161) \\
(46) \\
63 \\
(67) \\
(104) \\
(197) \\
(78) \\
-\end{array}$ & $\begin{array}{l}(41,94) \\
(39,162) \\
(31,470) \\
(2,237) \\
(29,119) \\
(3,319) \\
(28,266) \\
(38,576) \\
(4,362) \\
(0,761)\end{array}$ \\
\hline
\end{tabular}

\section{CASE SUMMARIES}

Table 7 shows exposure summaries for men who died of pancreatic cancer or leukaemia. Four of the seven men who died from leukaemia had been assigned to the chlorohydrin department $(0.7 \mathrm{exp})$. Causes of death on the death certificate were listed as acute leukaemia, acute myeloblastic leukaemia, and chronic myelogenous leukemin (2). Their average duration of assignments to the department was nine years and ranged from less than one to 16 years. No one was first assigned after 1937 and no one had ever been assigned to a department classified as intermediate or high exposure to EO. They died between 18 and 39 years after their first assignment to the department.

All of the EO assignments of the three remaining leukaemia decedents were in the lowest exposure departments and no two were assigned to the same department. The case who had the longest exposure died of chronic myelogenous leukaemia at age 53, 29 years after his first EO related assignment. The other two men died of myelogenous leukaemia and acute myeloblastic leukaemia. They spent under threes years in assignments to departments with potential exposure to EO and died less than four years aftero those assignments started.

Risk for pancreatic cancer was not among the priori hypotheses, yet seven men died of this disease (4.1 exp). Their death certificate diagnoses were: carcinoma of the pancreas (5), carcinoma, head of pancreas (1), and metastatic carcinoma, probably 3 pancreas (1). Six of these men had been assigned to the chlorohydrin department. Their dates of first assignment ranged from September 1929 to September 1944. The cumulative duration of assignments to the department ranged from two (the "probableo pancreatic cancer") to 30 years and averaged $12 \frac{3}{-}$. years. They died between 26 and 48 years after theiro first chlorohydrin assignment.

A pathological review of the cases of pancreatico

Table 6 Observed and expected deaths, relative risk estimates, and 95\% confidence limits for selected causes by cumulative duration in the chlorohydrin department

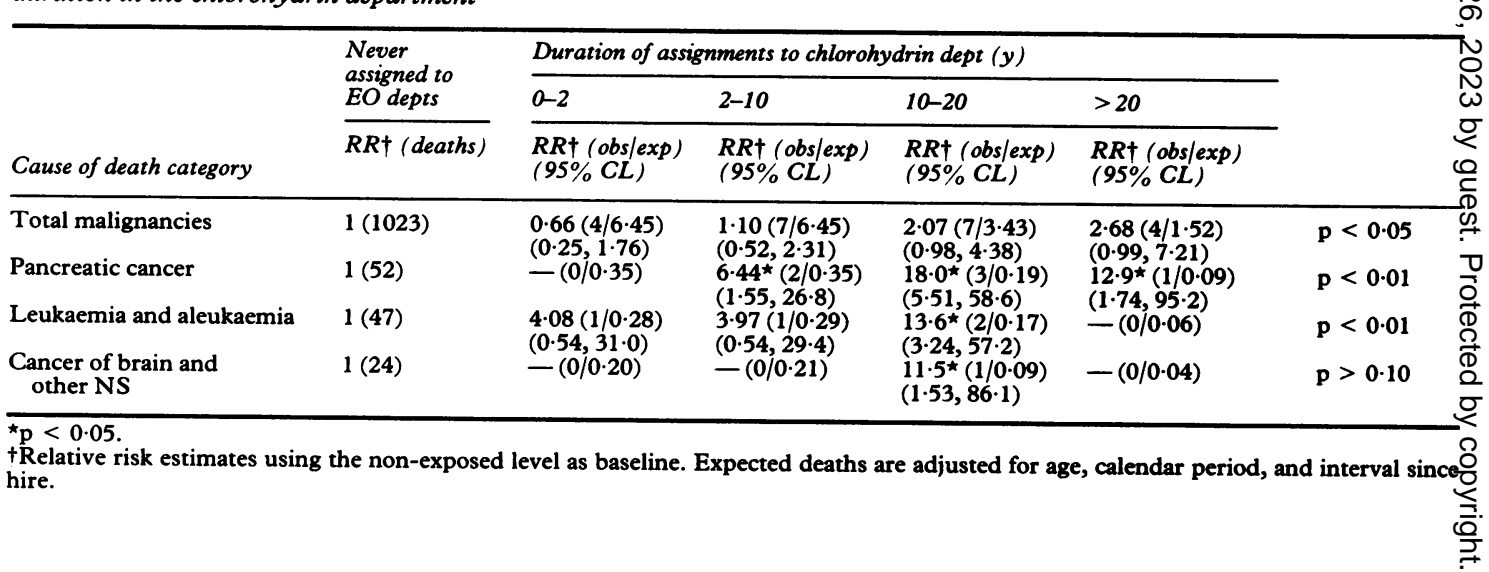


Table 7 Characteristics of decedents from pancreatic cancer and leukaemia and aleukaemia among men in the EO cohort, 1940-78

\begin{tabular}{|c|c|c|c|c|c|c|c|c|c|c|c|c|c|}
\hline \multirow{3}{*}{$\begin{array}{l}\text { Cause } \\
\text { code }\end{array}$} & \multirow{3}{*}{$\underset{r e v}{I C D A}$} & \multirow[b]{3}{*}{$\begin{array}{l}\text { Birth } \\
\text { year }\end{array}$} & \multirow{2}{*}{\multicolumn{2}{|c|}{ Age at }} & \multicolumn{5}{|c|}{ Duration $(y)$} & \multirow[b]{3}{*}{$\begin{array}{l}\text { Highest } \\
E O\end{array}$} & \multirow{2}{*}{\multicolumn{2}{|c|}{ Latency $(y)$}} & \multirow[b]{3}{*}{$\begin{array}{l}\text { Age at } \\
\text { death }\end{array}$} \\
\hline & & & & & \multirow[b]{2}{*}{$E O$} & \multirow[b]{2}{*}{ Chlor } & \multicolumn{3}{|c|}{ EO level } & & & & \\
\hline & & & $\begin{array}{l}\text { First } \\
E O\end{array}$ & $\begin{array}{l}\text { First } \\
\text { Chlor }\end{array}$ & & & Low & Int & High & & $\overline{E O}$ & Chlor & \\
\hline \multicolumn{14}{|c|}{ Pancreatic cancer } \\
\hline $\begin{array}{l}157.0 \\
157.9 \\
157.0 \\
157.0 \\
157.9 \\
157.9 \\
157.9\end{array}$ & $\begin{array}{l}8 \\
8 \\
7 \\
7 \\
8 \\
8 \\
8\end{array}$ & $\begin{array}{l}1905 \\
1903 \\
1907 \\
1904 \\
1908 \\
1914 \\
1913\end{array}$ & $\begin{array}{l}23 \\
26 \\
26 \\
30 \\
51 \\
26 \\
29\end{array}$ & $\begin{array}{l}23 \\
26 \\
26 \\
30 \\
29 \\
29\end{array}$ & $\begin{array}{r}25 \\
24 \\
34 \\
30 \\
4 \\
20 \\
2\end{array}$ & $\begin{array}{r}9 \\
19 \\
11 \\
30 \\
0 \\
18 \\
2\end{array}$ & $\begin{array}{r}22 \\
19 \\
11 \\
30 \\
4 \\
20 \\
2\end{array}$ & $\begin{array}{r}0 \\
5 \\
23 \\
0 \\
0 \\
0 \\
0\end{array}$ & $\begin{array}{l}2 \\
0 \\
0 \\
0 \\
0 \\
0 \\
0\end{array}$ & $\begin{array}{l}\text { High } \\
\text { Int } \\
\text { Int } \\
\text { Low } \\
\text { Low } \\
\text { High } \\
\text { Low }\end{array}$ & $\begin{array}{l}48 \\
43 \\
34 \\
31 \\
15 \\
29 \\
33\end{array}$ & $\begin{array}{l}48 \\
43 \\
34 \\
31 \\
26 \\
33\end{array}$ & $\begin{array}{l}71 \\
68 \\
60 \\
61 \\
66 \\
56 \\
62\end{array}$ \\
\hline \multicolumn{14}{|c|}{ Leukaemia and aleukaemia } \\
\hline $\begin{array}{l}204 \cdot 1 \\
205 \cdot 1 \\
207 \cdot 0 \\
205 \cdot 0 \\
205 \cdot 0 \\
204 \cdot 1 \\
205 \cdot 1\end{array}$ & $\begin{array}{l}6 \\
8 \\
8 \\
8 \\
8 \\
6 \\
8\end{array}$ & $\begin{array}{l}1898 \\
1908 \\
1891 \\
1908 \\
1922 \\
1908 \\
1925\end{array}$ & $\begin{array}{l}33 \\
26 \\
44 \\
29 \\
45 \\
46 \\
24\end{array}$ & $\begin{array}{l}33 \\
26 \\
44 \\
29 \\
- \\
-\end{array}$ & $\begin{array}{r}1 \\
8 \\
16 \\
11 \\
3 \\
3 \\
13\end{array}$ & $\begin{array}{r}1 \\
7 \\
16 \\
11 \\
0 \\
0 \\
0\end{array}$ & $\begin{array}{r}1 \\
8 \\
16 \\
11 \\
3 \\
3 \\
13\end{array}$ & $\begin{array}{l}0 \\
0 \\
0 \\
0 \\
0 \\
0 \\
0\end{array}$ & $\begin{array}{l}0 \\
0 \\
0 \\
0 \\
0 \\
0 \\
0\end{array}$ & $\begin{array}{l}\text { Low } \\
\text { Low } \\
\text { Low } \\
\text { Low } \\
\text { Low } \\
\text { Low } \\
\text { Low }\end{array}$ & $\begin{array}{r}18 \\
36 \\
39 \\
34 \\
4 \\
3 \\
29\end{array}$ & $\begin{array}{l}18 \\
36 \\
39 \\
34 \\
- \\
-\end{array}$ & $\begin{array}{l}52 \\
62 \\
82 \\
63 \\
49 \\
49 \\
53\end{array}$ \\
\hline
\end{tabular}

^Employee spent less than 0.5 years in a "high" EO department. Duration in "high" is 0 due to rounding.

cancer and leukaemia based on hospital records confirmed the death certificate diagnoses for all but two individuals. The primary cancer site was judged unknown for one case of pancreatic cancer and the medical record for one case of leukaemia could not be obtained.

\section{Discussion}

The study was originally conceived as an integral component of the cohort mortality study of UCC's three facilities in the Kanawha Valley of West Virginia that was conducted in collaboration with the National Institute for Occupational Safety and Health (NIOSH). It was agreed to perform certain chemical and process specific retrospective cohort studies once follow up for the entire population was complete and sufficient information on chemical production departments had been compiled. The present study represents the first complete exposure specific research using the database.

Study departments were ranked according to relative potential for exposure according to the nature of their routine production practices determined using the best available evidence. Medical records of acute exposures to EO support the ranking scheme with respect to the frequency of inhalation and dermal exposures. The ranking scheme is also supported by industrial hygiene surveys of these and other UCC facilities. Based on estimates of operators' TWA8 EO exposures at the UCC Texas City, Texas, plant, exposure levels in direct oxidation EO production were probably in the range of 10-20 ppm. ${ }^{24}$ Levels in EO production using the chlorohydrin process were probably somewhat higher, since (1) the technology, construction materials, and work practices were from an earlier era, (2) there was no control room, and (3) the production equipment was indoors. Based on breathing zone samples collected from 1976 to 1978 at the South Charleston and Institute plants, continuous exposure levels in departments using EO were in the order of $<1-3 \mathrm{ppm}$ (possibly an order of magnitude lower than those in production departments).

There were no observed associations of stomach or brain cancer mortality with duration of assignments to study departments. In addition, the risk of death due to leukaemia was not raised in the subcohort exposed to the highest EO levels or in the entire cohort after removal of the chlorohydrin group. Supplementary analyses by level of "integral EO exposure" (level of exposure (high $=3$, intermediate $=2$, low $=1$ ) $\times$ duration) were also conducted and yielded similar results. The relative risks of both leukaemia and pancreatic cancer, however, were shown to be strongly associated with duration of assignment to the chlorohydrin department, even after the incorporation of appropriate latent intervals.

Results of proportional hazards modelling were consistent with those of the categorical analyses. ${ }^{25}$ No index of EO exposure was statistically significant when present in a model containing a term for chlorohydrin department duration, whereas the chlorohydrin duration variable was highly significant and remained so for all induction periods examined $(0,5,10$, and 20 years).

The chlorohydrin department started up in November 1925. Until September 1931 the department produced ethylene chlorohydrin exclusively. The crude ethylene chlorohydrin was pumped to the 
EO production department and used for EO production (chlorohydrin process). After that time, three of the seven reaction towers were made available for "special production" of propylene chlorohydrin until sometime between the late 1930s and early 1940 s. The equipment was then infrequently used to manufacture bis-chloroethyl ether (BCEE) and dichloroethane or concentrated ethylene chlorohydrin. Both processes used EO and according to the best available information, they were run only sporadically and production volumes were small. These processes represented the sole uses of EO in the chlorohydrin department. The only other opportunity for exposure to EO was the result of fugitive emissions from other EO departments in the same building. Ethylene chlorohydrin production ceased in 1957.

Four of the seven leukaemia decedents and six of the seven pancreatic cancer decedents in the EO cohort had been assigned to the chlorohydrin department. All four leukaemia decedents were first assigned in the 1930s. The six men in the chlorohydrin subcohort who died of pancreatic cancer were first assigned to the department before 1945 . Nine of the 10 decedents with leukaemia and pancreatic cancer worked in the chlorohydrin department between 1935 and 1945 and only three of the ten had additional work experience in that department after ethylene chlorohydrin production ceased.

Because the chlorohydrin department had been operating for over 15 years by the beginning of study follow up, there was ample opportunity for selection out of the cohort. Given the distribution of deaths by chlorohydrin duration and that selection out was most likely among men with shorter assignments, it is unlikely that bias could have artificially created the observed trends with duration of chlorohydrin assignments.

The conditions of EO use in the chlorohydrin department were probably not unique, as ad hoc small volume "special production" occurred in many study departments. Thus the possibility that the chlorohydrin results were due to any special circumstances of exposure to EO in that department seems remote. The relative risk of leukaemia (and pancreatic cancer) mortality was found not to be associated with assignment to EO production units or with duration or "integral EO exposure" among the 1896 men in the cohort never assigned to the chlorohydrin department. Inferences from the results in this subgroup to similarly exposed groups are limited by the small cohort size. This is partially offset by the long average period of observation (almost 20 years). Omitting the chlorohydrin subcohort from the total study population and allowing for a latency period (time from first EO related assignment) of ten years, the leukaemia SMR was 65 ( $1 \mathrm{obs} / 1.5 \mathrm{exp}, 95 \% \mathrm{CL}=3,310)$ or $140(3 \mathrm{obs} / 2 \cdot 1$ exp, $95 \% \mathrm{CL}=27,409$ ) if the latency requirement is?. dropped.

During the relevant period, the opportunity for? exposure in the chlorohydrin department was greatest for substances related to the production os ethylene chlorohydrin, including the byproducts dichloroethane and BCEE. Ethylene chlorohydrin has not been found to be carcinogenic when adminis tered to rats by gavage or by dermal application to rats or mice. ${ }^{2627}$ It was only inconsistently car:cinogenic by subcutaneous injection. ${ }^{26}{ }^{28}$ On the otherw hand, the carcinogenicity of dichloroethane has been shown in rats and mice of both sexes. ${ }^{29}{ }^{30}$ Oral dosing of mice with BCEE has produced an increased incidence of hepatomas ${ }^{31}$ but this result has been questioned as a reliable indication of true car $\vec{\sim}$ cinogenic potential. ${ }^{32}$ Other studies using both rats and mice have shown no evidence of carcinogenicity. ${ }^{33-37}$

The results of this study are best viewed in the context of the existing published epidemiologica? studies of EO exposed populations. Hogstedt et a $\bar{L}$. reported the first putative excess of leukaemi\& associated with EO among a group employed in $a$ factory in which a mixture of EO and methyl formate was used as a sterilant. ${ }^{10}$ This was actually the report of a cluster and factors other than exposure to EO do not appear to have been evaluated. The second excess of leukaemia, also reported by Hogstedt et al $\mathbb{\mathbb { D }}$ occurred among a population employed as operators in a chemical production facility that manufactureof EO by the chlorohydrin process. ${ }^{11}$ Numerous chemicals were present in this chlorohydrin based EO production unit and in other chemical production at the plant. These EO workers were reported to have spent more than one hour per shift in the chlorohydrin room and, furthermore, were reportedB. to have tasted the chemical reaction product to assessin the result of EO synthesis. Three of the remaining EO production cohorts studied by other inves-o tigators included plants that produced EO by the chlorohydrin process. ${ }^{1315}$ The findings from thes studies are not consistent with those reported by Hogstedt et al. The observed and expected numbers of deaths from leukaemia were $1 v 0 \cdot 2$ (A M Thiess $e$ i $a l$, international symposium for the prevention of occupational cancer, Helsinki, 1982), 2 v 2.4 (N $\mathbb{N}^{\mathrm{O}}$ Kiesselbach et al, Stockholm, 1988) and $3 v 2 \cdot 1$. 19 The three cases from the Gardner study did note occur among men assigned to EO production (byes either process). Nor did these individuals work in ethylene chlorohydrin production.

In the present study no deaths from leukaemia⿱ were observed among men assigned to EO produc $\frac{?}{D}$ tion. With the exception of ingestion of the reaction 2 mixture, the exposure conditions described by Hogstedt et al are, at least qualitatively, similar to those in the South Charleston plant. ${ }^{11}$ The inter 
pretation of the leukaemia-chlorohydrin results, however, is further complicated by the fact that the decedents from leukaemia were first assigned to the chlorohydrin department between 1931 and 1937. This finding could have been due to chance or it could result from qualitatively or quantitatively different pre versus post 1940 exposures, or both.

As to stomach cancer, Hogstedt's findings may have been related to the ingestions of the EO reaction mixture, which would have contained EO, ethylene glycol, ethylene chlorohydrin, dichloroethane, BCEE, and other substances. Dunkelberg has shown cancer of the forestomach in rats exposed to EO by gavage. $^{38}$

Pancreatic cancer was not found in Hogstedt's cohorts but it was raised in the EO cohorts studied by Morgan et al. ${ }^{14}$ In the former study EO was produced by direct oxidation only. Both pancreatic cancer and pancreatitis have been observed in cohorts exposed to short chain chlorinated hydrocarbons. ${ }^{39-41}$ There is also limited and inconsistent epidemiological evidence concerning pancreatic cancer and employment in the dry cleaning industry. ${ }^{42-44}$

Together with the failure to support independent EO associations, the chlorohydrin department results suggest that the observed excesses of leukaemia and pancreatic cancer were primarily associated with the production of ethylene chlorohydrin or propylene chlorohydrin, or both. These results emphasise the importance of examining additional concurrent/asynchronous exposures among EO exposed (or other) occupational populations.

The prediction of human risk related to EO is problematical. The mutagenicity, genotoxicity, and carcinogenicity of EO have been clearly shown in experimental studies. Yet overall, epidemiological publications do not show an independent EO effect. Inconsistencies of the human and experimental data would be better understood if the pharmacokinetics of EO were known.

We gratefully acknowledge the National Institue of Occupational Safety and Health for their continual cooperation and scientific reviews. We also thank Dr $M$ Jane Teta for reviewing and editing the manuscript and Messrs Don Gosselin and Tony Soto for their technical help.

Requests for reprints to: Dr H L Greenberg, ARCO, 515 South Flower Street, Los Angeles, California 90071.

1 International Trade Commission. Preliminary report on US production of selected synthetic organic chemicals (including synthetic plastics and resin materials) third quarter, fourth quarter, and cumulative totals, 1987. Washington: ITC, 1988. (SOC series C/P-87-5.)

2 Koketsu M. Ethylene oxide industry-wide hygiene study. (Submitted to the National Institute for Occupational Safety and
Health under contract No 210-76-0162.) Menlo Park, CA: SRI International, 1978.

3 Frankel-Conrat $H$. The action of 1,2-epoxides on proteins. $J$ Biol Chem 1944;154:227-38.

4 Ehrenberg L, Heische KD, Osterman-Golkar S, Wennberg $I$. Evaluation of genetic risks of alkylating agents: tissue doses in the mouse from air contaminated with ethylene oxide. Mutat Res 1974;24:83-103.

5 Calleman CJ, Ehrenberg L, Jansson B, et al. Monitoring and risk assessment by means of alkyl groups in hemoglobin in persons occupationally exposed to ethylene oxide. J Environ Pathol Toxicol 1978;2:427-42.

6 Lynch DW, Lewis TR, Moorman WJ, et al. Carcinogenic and toxicologic effects of inhaled ethylene oxide and propylene oxide in F344 rats. Toxicol Appl Pharmacol 1984;76:69-84.

7 Snellings W, Weil C, Maronpot R. A two-year inhalation study of the carcinogenic potential of ethylene oxide in Fischer 344 rats. Toxicol Appl Pharmacol 1984;5:105-17.

8 Garman RH, Snellings WM, Maronpot RR. Brain tumors in F344 rats associated with chronic inhalation exposure to ethylene oxide. Neurotoxicology 1985;6:117-38.

9 NTP (National Toxicology Program). Toxicology and carcinogenesis studies of ethylene oxide (cas No 75-21-8) in BGC3F, mice (inhalation studies). Research Triangle Park, NC: NTP. US Department of Health and Human Services, 1987. (Tech rep series No 326.)

10 Hogstedt C, Malmqvist N, Wadman B. Leukemia in workers exposed to ethylene oxide. $J A M A 1979 ; 241: 1132-3$.

11 Hogstedt C, Rohlen O, Berndtsson BS, Axelson O, Ehrenberg L. A cohort study of mortality and cancer incidence in ethylene oxide production workers. $\mathrm{Br} \mathrm{J}$ Ind Med 1979; 36:276-80.

12 Hogstedt C, Aringer L, Gustavsson A. Epidemiologic support for ethylene oxide as a cancer-causing agent. JAMA 1986; 255:1575-8.

13 Thiess AM, Frentzel-Beyme R, Link R, Stocker WG. Mortality study on employees exposed to alkylene oxides (ethylene oxide/propylene oxide) and their derivatives. In: Prevention of occupational cancer. Geneva: International Labour Office, 1981:249-59. (Occupational Safety and Health series No 46.)

14 Morgan RW, Claxton KW, Divine BJ, Kaplan SD, Harris VB Mortality among ethylene oxide workers. J Occup Med 1981;23:767-9.

15 Gardner MJ, Coggon D, Pannett B, Harris EC. Workers exposed to ethylene oxide: a follow-up study. $\mathrm{Br} J$ Ind Med 1989;46:860-5.

16 Rinsky RA, Ott MG, Ward E, Greenberg H, Halperin W, Leet $T$. Study of mortality among chemical workers in the Kanawha Valley of West Virginia. Am J Ind Med 1988; 13:429-38.

17 Ott MG, Teta MJ, Greenberg HL. Assessment of exposure to chemicals in a complex work environment. Am J Ind Med (in press).

18 Waxweiler RJ, Beaumont JJ, Henry BA, et al. A modified lifetable analysis system for cohort studies. J Occup Med 1983; 25:115-24.

19 Rothman KJ, Boice JD. Epidemiologic analysis with a programmable calculator. Washington: US Government Printing Office, 1979:28-9. (DHEW publ No (NIH) 79-1649.)

20 Mantel N. Chi-square tests with one degree of freedom; extensions of the Mantel Haenszel procedure. Journal of the American Statistical Association 1963;58:690-700.

21 Hakulinen T. A Mantel-Haenszel statistic for testing the association between a polychotomous exposure and a rare outcome. Am J Epidemiol 1981;113:192-7.

22 Robins J, Greenland S, Breslow N. A general estimator for the variance of the Mantel-Haenszel odds ratio. Am J Epidemiol 1986;124:719-23.

23 Pasternack BS, Shore RE. Statistical methods for assessing risk following exposure to environmental carcinogens. In: Whittemore AS, ed. Environmental health: quantitative methods. Philadelphia: Society for Industrial and Applied Mathematics, 1977:49-71.

24 Joyner RE. Chronic toxicity of ethylene oxide. Arch Environ Health 1964;8:700-10.

25 Greenberg HL. A mortality study of employees engaged in the industrial production of ethylene oxide or ethylene oxide-based products. Ann Arbor, Michigan: University Microfilms International, 1988. (Doctoral dissertation at the New York University Graduate School of Arts and Science, New York.)

26 Dunkelberg $\mathrm{H}$. Carcinogenic activity of ethylene oxide and its reaction products 2 -chloroethanol, 2-bromoethanol, ethylene 
glycol and diethylene glycol: II. Testing of 2-chloroethanol and 2-bromoethanol for carcinogenicity. Zentralbl Bakteriol Mikrobial Hyg (B) 1983;174:383-404.

27 NTP (National Toxicology Program). Toxicology and carcinogenesis studies of 2-chloroethanol (ethylene chlorohydrin) (cas No 107-07-3) in F344/N rats and Swiss CD-1 mice (dermal studies). Research Triangle Park, NC: NTP. US Department of Health and Human Services, 1985. ((NIH) tech rep series No 275.)

28 Mason M, Cate C, Baker J. Toxicology and carcinogenesis of various chemicals used in the preparation of vaccines. Clin Toxicol 1971;4:185-204.

29 NTP (National Toxicology Program). Bioassay of 1,2dichloroethane for possible carcinogenicity (cas No 107-06-2). Research Triangle Park, NC: NTP. US Department of Health, Education and Welfare, 1978. ((NIH) tech rep series No 55.)

30 International Agency for Research on Cancer. Monographs on the evaluation of carcinogenic risk of chemicals to humans. Vol 20. Some halogenated hydrocarbons. Lyon: IARC, 1979.

31 Innes JRM, Ulland BM, Valeria MG, et al. Bioassay of pesticides and industrial chemicals for tumorigenicity in mice. J Natl Cancer Inst 1969;42:1101-14.

32 Maronpot RR, Haseman JK, Boorman GA, et al. Liver lesions in B6C3F1 mice: the National Toxicology Program, experience and position. Arch Toxicol 1987; suppl 10:10-26.

33 Van Duuren BL, Katz C, Goldschmidt BM, et al. Carcinogenicity of halo-ethers. II. Structure-activity relationship of analogues of bis(chloromethyl)ether. J Natl Cancer Inst 1972;48:1431-9.

34 Theiss JC, Stoner GD, Shimkin MB, et al. Test for carcinogenicity of organic contaminants of United States drinking waters by pulmonary tumor response in strain A mice. Cancer Res 1977;37:2717-20.
35 Jorgenson TA, Rushbrook CJ, Newell GW, et al. Study of thẹ mutagenic potential of bis (2-chloroethyl) and bis (2-chloro-: isopropyl) ethers in mice by the heritable translocation test Mutat Res 1978;53:124 (abstract.)

36 Weisburger EK, Ulland BM, Nam J, Gart JJ, Weisburger JHO Carcinogenicity tests of certain environmental and industriaE

37 Norpoth K, Heger M, Muller G, Mohtashamipur E, Kemena A Witting C. Investigations of metabolism, genotoxic effects andD carcinogenicity of 2,2-dichlorodiethyl ether. I Natl Cancer Res Clin Oncol 1986;113:125-30.

38 Dunkelberg $\mathrm{H}$. Carcinogenicity of ethylene oxide and 1,2propylene oxide upon intragastric administration to rats. $\mathrm{Br} \overrightarrow{\mathrm{C}}$ Cancer 1976;46:924-33.

39 Braganza J, Jolley JE, Lee WR. Occupational chemicals and $\vec{\omega}$ pancreatitis: a link? Int J Pancreatol 1986;1:9-19.

40 Ott MG, Carlo GL, Steinberg S, Bond GG. Mortality among employees engaged in chemical manufacturing and relatedD activities. Am J Epidemiol 1985;122:311-22.

41 Hearne FT, Grose F, Pifer JW, Friedlander BR, Raleigh RL: Methylene chloride mortality study: dose-response charac- - V terization and animal model comparison. J Occup Med $\square$ 1987;29:217-27.

$42 \mathrm{Lin} \mathrm{RS,} \mathrm{Kessler} \mathrm{II.} \mathrm{A} \mathrm{multifactorial} \mathrm{model} \mathrm{for} \mathrm{pancreatic} \mathrm{cancer}$ in man. JAMA 1981;245:147-52.

$43 \mathrm{Katz}$ RM, Jowett $\mathrm{D}$. Female laundry and dry cleaning workers in Wisconsin: a mortality analysis. Am J Public Health $1981 ;$ 71:305-7.

44 Brown DP, Kaplan SD. Retrospective cohort mortality study of dry cleaner workers using perchloroethylene. J Occup Med. 1987;29:535-41.

Accepted 20 October 1989

\section{Destruction of manuscripts}

From 1 July 1985 articles submitted for publication will not be returned. Authors whose papers are rejected will be advised of the decision and the manuscripts will be kept under security for three months to deal with any inquiries and then destroyed. 